\title{
ランダム路面入カシミュレーションを用いた 油圧アクティブサスペンションの最適設計手法*
}

\author{
古市崇*1, 福島 直 ${ }^{* 2}$, 萩 原一 郎*3
Optimal Design of Active Suspension by Simulating with Random Road Surface

\author{
Takashi FURUICHI, Naoto FUKUSHIMA and Ichiro HAGIWARA*4
}

${ }^{* 4}$ Department of Mechanical Sciences and Engineering, Tokyo Institute of Technology, 2-12-1 Ookayama, Meguro-ku, Tokyo, 152-0033 Japan

\begin{abstract}
This research presents an optimal design of active suspension, simulated on random road surface. In this work damper and spring are considered as sky-hook control gain and mechanical parameters of active suspension. Besides, the 8 -DOF vehicle model is used for calculating the simulation. The function of energy consumption and vehicle vibration is defined as the criteria. Hence a research on the design parameters of the above mentioned criteria gives an optimal result on the vehicle vibration and energy consumption.
\end{abstract}

Key Words: Active Suspension, Optimal Design, Computer Aided Analysis, Hydraulic System, Simulation

\section{1. 緒論}

自動車関連技術は新たな転換期を向かえ, 燃料電池 自動車などが登場している．燃料電池自動車では動力 発生部分からの音および振動は低減され, 乗り心地や 車内こもり音に新たな性能が求められるようになる.

乗り心地性能の向上技術では, アクティブサスペン ションが乗用車で利用されるようになり, 最適制御理 論など各種の先進的な制御理論の適用が検討されてき た(1)(2). しかし，アクティブサスペンションを設計す るためには制御だけでなく, 機構系に対しても設計法 を検討する必要がある。また, 油圧アクティブサスペ ンションが一般的に利用されない背景の一つとして, 油圧消費による燃費への影響が考えられる．近年で は, 燃費に対する性能も重視する傾向があるため, 油 圧消費流量も考慮に入れた乗り心地性能を向上させる 最適化手法が必要である.

\footnotetext{
* 原稿受付 2003 年 11 月 18 日.

*1 東京工業大学大学院理工学研究科機械物理工学専攻 (w152 8550 東京都目黒区大岡山 2-12-1) [現: 本田技術研究所].

*2 正員, フェロー, シミュレーション技術研究所( $1248-0011$ 鎌倉市扇ガ谷 2-17-15).

*3 正員, フェロー, 東京工業大学大学院理工学研究科機械物理 工学専攻.

E-mail : hagiwara@mech.titech.ac.jp
}

本研究では, 福島らによって開発されたランダム路 面入力シミュレーション(3)を使用することにより, 前 後輪にアクティブサスペンションを組込んだ状態でシ ミュレーションを行う. 車両モデルは 8 自由度上下振 動モデルを使用し, 一輪モデルに比べより実車に近い モデルである.このモデルを使用して乗り心地性能お よび油圧消費流量性能について同時に最適化を行うこ とにより油圧アクティブサスペンションの設計手法を 提案する.

\section{2. 主 な 記 号}

$J_{a}:$ 乗り心地評価関数

$J_{c}:$ 消費流量評価関数

$x_{2}:$ ボディ中心位置の変位

$\phi_{2}:$ ボディ中心位置の回転角度

$C_{s f}, C_{s r}$ : スカイフックダンパ減衰定数

$C_{v f}, C_{v r}:$ 圧力制御バルブ減衰定数

$C_{a f}, C_{a r}:$ アキュームレー夕減衰定数

$K_{a f}, K_{a r}:$ アキュームレータばね定数

ここで添字 $f$ はフロントサスペンションの, また $r$ はリアサスペンションのパラメータであることを示 す. 


\section{3. 車両モデル}

本研究では, 図 1 に示す 8 自由度上下振動モデルを 使用する。このモデルでは左右対称性を考虑した片側 モデルである.入力は, 路面の表示方法として ISO 規格(4)を使用し, 前後輪で車速に基づく時間遅れを考 慮して入力する.

このシミュレーションでは, 路面は極良路とし, 車 速は $60 \mathrm{~km} / \mathrm{h}, 20$ 秒間の車両の運動を解析する.ま た, 図 1 に表示しているサスペンション部分は, 後に 表示するアクティブサスペンションモデルへ変更す る.

4. アクティブサスペンションモデル化

$4 \cdot 1$ アクティブサスペンションの構成 本研究 で使用するアクティブサスペンションは福島らが開発 した電磁比例圧力制御バルブ方式(5) のものを使用す

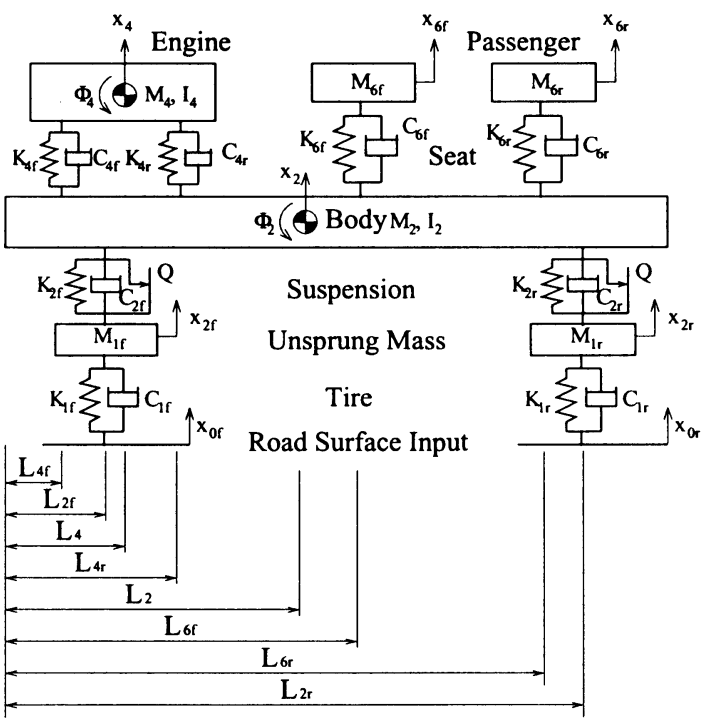

Fig. 1 8-DOS vehicle model

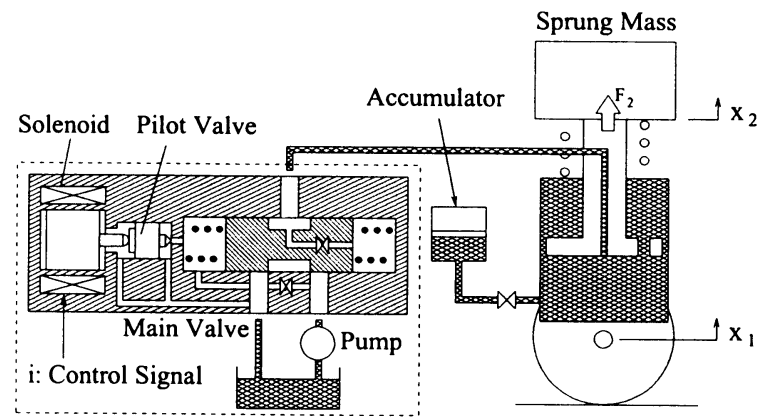

Fig. 2 Electro-hydraulic pressure control unit
る。また，制方方式はスカイフック制御を使用する。 このアクティブサスペンションモデルを図 2 に示す. このモデルでは，ポンプから送られる高圧の作動油が， 圧力制御バルブに導かれ，スプールが中立時には全閉， 右に移動すると油圧シリンダ側に開口され，逆にスフ ールが左に移動すると, 油圧シリンダとリターン側が つながるように連続的に調整される。

$4 \cdot 2$ 油圧ユニットのモデル化 本研究では, 簡 略化のため, 図 2 のメインバルブおよび油圧ポンプ部 の機構を図 3 に示すように簡略化する。この変更によ り,アクチュエータの応答性が実際よりも安定したも のとして扱うことになるが, 制御系の実際とモデルと のずれは拘束条件として，モデル内に組込むこととす る.

$4 \cdot 3$ アクティブサスペンションのモデル化以 上を考慮して，モデル化を行うと図4のようになる。

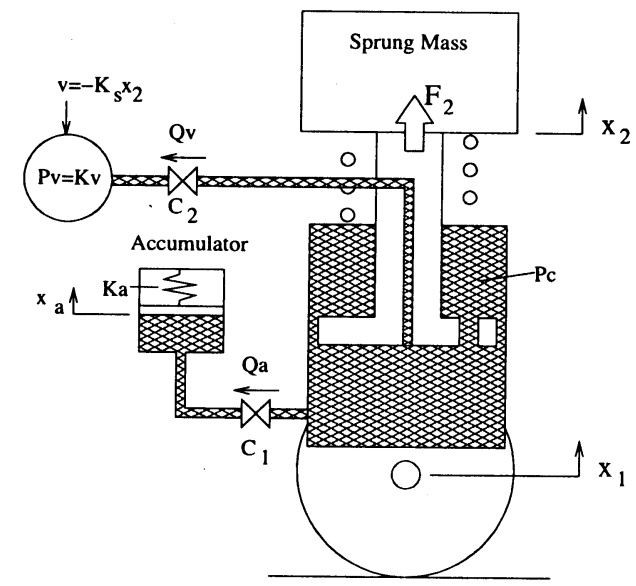

Fig. 3 Hydraulic unit model

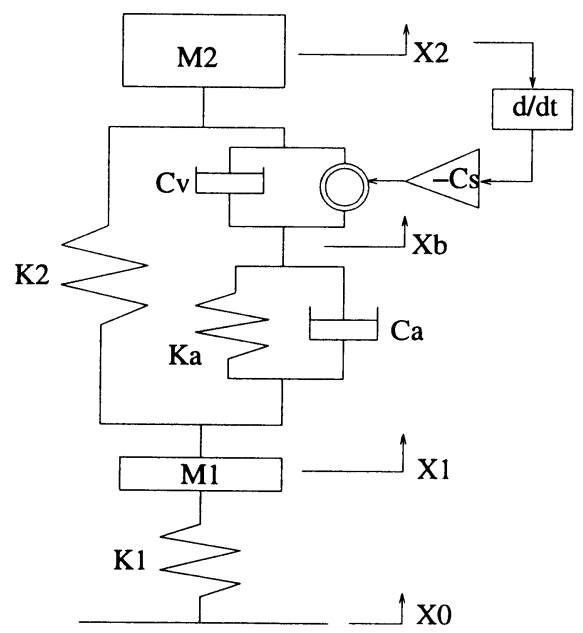

Fig. 4 Active suspension model 
このモデルを 8 自由度シミュレーションの前後輪に入 れ込み, 後のシミュレーションを実行する。この 2 自 由度モデルにおいて, 減衰力特性は油圧系全体で発生 することになり, $\left(\dot{x}_{1}-\dot{x}_{2}\right)$ に対する $F_{2}$ の伝達関数 $H_{a}(s)$ を求めると次式のようになる.

$$
H_{a}(s)=C_{v} \frac{C_{a} s+K_{a}}{\left(C_{v}+C_{a}\right) s+K_{a}}
$$

\section{5. 最 適 設 計}

以上の検討結果より最適設計問題を定式化する. 乗 り心地性能はばね上振動加速度 $\ddot{x}_{2}$ で, また消費流量 は $\left|\dot{x}_{b}-\dot{x}_{2}\right|$ で評価できる.ここで $x_{b}$ は, 図 4 におい て,アクチュエータ下部の変位である。それぞれの性 能を評価する関数を乗り心地性能については $J_{a}$, 消費 流量については $J_{c}$ を評価関数とし次式で定義する.

$$
\begin{aligned}
& J_{a}=\sum\left\{\ddot{x}_{2 f}^{2}(n)+\ddot{x}_{2 r}^{2}(n)\right\} \cdots \cdots \cdots \cdots \cdots \cdots \cdots \cdots(2 \\
& J_{c}=\sum\left\{\left|\dot{x}_{b f}(n)-\dot{x}_{2 f}(n)\right|+\left|\dot{x}_{b r}(n)-\dot{x}_{2 r}(n)\right|\right\}
\end{aligned}
$$

ここで, $x_{2 f}, x_{2 r}$ は前後輪上部のボディの変位であり, 8 自由度車両モデルのパラメータ $x_{2}, \phi_{2}$ を使用して次 のように表される。

$$
\begin{aligned}
& x_{2 f}=x_{2}-\left(L_{2}-L_{2 f}\right) \phi_{2} \\
& x_{2 r}=x_{2}+\left(L_{2 r}-L_{2}\right) \phi_{2}
\end{aligned}
$$

$J_{a}$ は, 入力がランダムであることを考慮し, シミュ

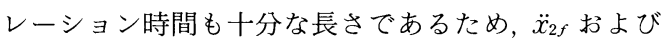
$\ddot{x}_{2 r}$ の周波数応答を積分したものに近い. また, $J_{c} に$ ついて, 消費流量は, 值の大きなものに重みがかから ず一定の評価を行う必要があると考えたため, 值の絶 対值をとっている.

また, 乗り心地性能と消費流量を同時に最適化する ための評価関数を次式で定義する.

$$
J=J_{a}+r J_{c} \cdots
$$

ここで, $r$ は重み定数である.

$5 \cdot 1$ 設計パラメータの制約条件 実際のシステ ム設計では明らかに経験的な制約条件がある。これら の制約条件を定式化するとともに最適化を行うシステ ムへ制約条件として組込んでおく必要がある.

$5 \cdot 1 \cdot 1$ タイヤ接地性の拘束 ばね下共振周波数 近傍でのダンピングが不足すると走行時にタイヤと路 面の接地加重変動が増しタイヤのグリップ性能を低下 させて走行安定性を損なう。これを防ぐため, ばね下 減衰比 $\zeta_{1}$ を一定量確保する必要がある. 本システム のばね下減衰は式 (1)で示される周波数依存特性を有 しており, ばね下共振周波数近傍の $10 \mathrm{~Hz}$ 付近では下 限值 $C_{a} C_{v} /\left(C_{a}+C_{v}\right)$ に近い. よって, 必要な減衰比 の下限值を $\zeta_{1}^{*}=0.17$ とし, 次の不等式拘束条件を課
すことにする。

$$
\frac{C_{a} C_{v}}{C_{a}+C_{v}} \geq 2 \zeta_{1}^{*} \sqrt{M_{1} K_{1}}
$$

$5 \cdot 1 \cdot 2$ スカイフックダンパゲインの拘束 スカ イフックダンパ制御ではばね上質量に加速度センサを 設置してこの信号を積分して速度信号を得ている．積 分による定常オフセットの発生を防止するためフィル 夕を用いて対策しているが，ゲインをあげすぎるとば ね上共振を抑えても高周波域で逆に振動が増す傾向に なる.フィルタ性能にもよるが, スカイフックダンパ の減衰比にも上限值 $\zeta_{s}^{*}$ 設けざるを得ないのが現状 である.したがって $C_{s}$ に関して次の拘束条件を課 す.

$$
C_{s} \leq 2 \zeta_{s}^{*} \sqrt{M_{2} K_{2}}
$$

ここで $\zeta_{s}^{*}=0.42$ とする.この制約条件は図 4 で示さ れる 2 自由度モデルであるので, これを 8 自由度のモ デルに組込むために $M_{2}$ を変更する必要がある．前後 輪それぞれサスペンションにかかる静的な分配力をそ れぞれ $M_{2 f}, M_{2 r}$ として $M_{2}$ の代わりとして扱うこと とする。

$5 \cdot 1 \cdot 3$ 制御応答性の拘束制御を確実なものと するため制御系の応答性の下限值を指定する必要があ る.アクチュエータ系のカットオフ周波数の下限值を $\omega^{*}$ とすると次の不等式拘束条件を得る.

$$
\frac{K_{a}}{C_{a}+C_{v}} \geq \omega^{*}
$$

$\omega^{*}$ は車両の代表的な固有值例えばヨー共振周波数程 度に選ぶ. 本研究では $\omega^{*}=2 \pi \times 1.3$ とする。

$5 \cdot 2$ パラメータ最適化本研究では最適化を以 下のステップで行う。

1. 不等式拘束条件を等式拘束条件とみなしてシステ ムに組込み評価関数を最小とする最適パラメー夕 を求める.

2. 等式拘束条件とみなしたことの妥当性を確認す る.

式(8)を等式とすることにより $C_{s}$ が確定し, 式 (9)を等式とすることにより $K_{a}$ が $C_{a}$ と $C_{v}$ 。值で 確定する.さらに式 $(7)$ を等式とすることにより $C_{a}$ は次式で表される.

$$
C_{a}=\frac{2 C_{v} \zeta_{1}^{*} \sqrt{M_{1} K_{1}}}{C_{v}-2 \zeta_{1}^{*} \sqrt{M_{1} K_{1}}}
$$

よって, 設計変数となるのは $C_{v}$ のみとなり, 本研究 では前後輪を考慮するため $C_{v f}$ および $C_{v r}$ の 2 設計 変数の最適化となる.つまり, 前後輪別々にパラメー 夕の最適化を行う. $r=1.6$ における最適化の結果を 図 5 に示す. 図 5 から最適化の結果を読み取ることは 


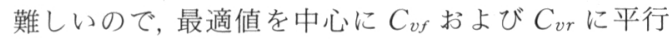
な面に投影し, 最適值を $J_{\mathrm{opt}}$ とした場合に $(J-$ $\left.J_{\mathrm{opt}}\right) / J_{\mathrm{opt}}$ で正規化したものを図 6 に示す。ここで, 重 み $r$ を変化させることで乗り心地性能を重視した最 適化や消費流量低減を重視した最適化を行うことがで きる。

本研究では, 重み $r$ にいて, 1.0, 1.6, 2.4の三つ のパターンについて計算を行う. $r=1.6$ の場合は, 実際のサスペンション開発において試行錯誤的に求め られた最適解に近いため, 本研究ではこれを基準值と した。またそれぞれの場合の詳細な結果を表 1 に示

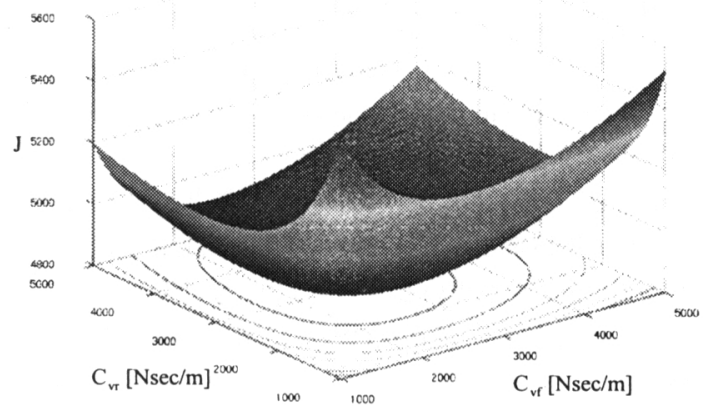

Fig. 5 Result of optimization

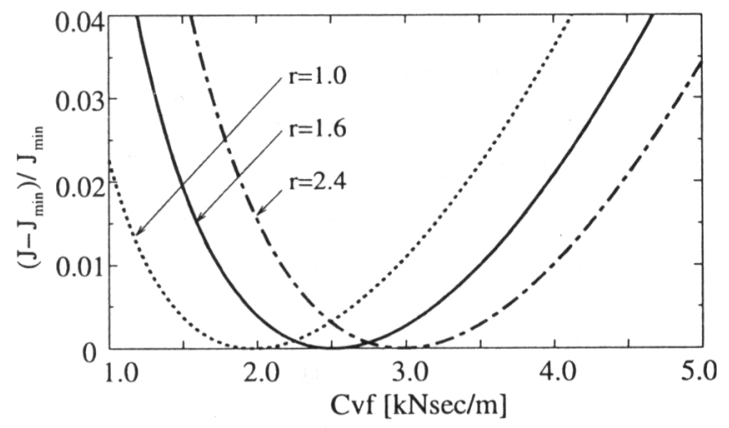

(a) Front parameters

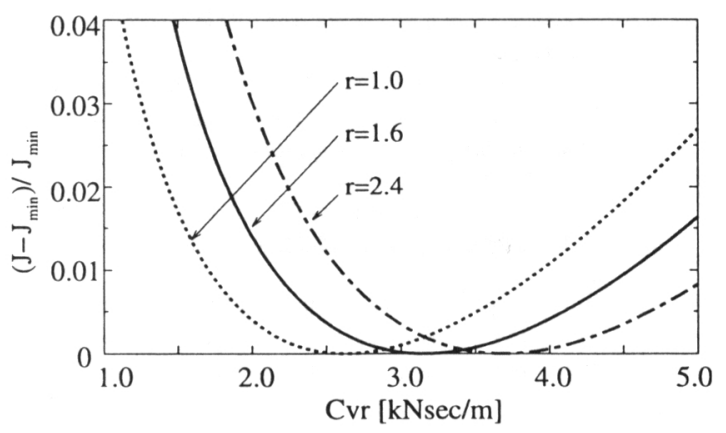

(b) Rear parameters

Fig. 6 Calculated results of criteria $J$
す.

さらに, $r$ と最適值 $J_{a}$ と $J_{c}$ との関係を図 7 に示 す。この結果より, $r$ を変更した場合に, 乗り心地性 能と消費流量性能が単調に変化していることがわか る.

またこれらの数値結果に対して, 等式拘束条件を適 用したことについての妥当性を検討する. 図 8 に $r=$ 1.6 の場合の最適パラメータを適用し, 一つのパラメ ー夕を最適解の $\alpha$ 倍したときの評価関数 $J$ の值の変 化を示す. $C_{s f}, C_{s r}$ は $\alpha \leq 1$ の領域で, またそれ以外 のパラメータについては $\alpha \geq 1$ の領域で単調であり,

Table 1 Optimum parameter

\begin{tabular}{|c|c|c|c|c|c|c|c|c|}
\hline$r$ & $C_{s f}$ & $C_{s r}$ & $C_{v f}$ & $C_{v r}$ & $C_{a f}$ & $C_{a r}$ & $K_{a f}$ & $K_{a r}$ \\
\hline \hline 1.0 & 1.74 & 1.76 & 1.97 & 2.62 & 2.46 & 1.88 & 36.20 & 36.75 \\
\hline 1.6 & 1.74 & 1.76 & 2.51 & 3.15 & 1.94 & 1.68 & 36.35 & 39.43 \\
\hline 2.4 & 1.74 & 1.76 & 2.98 & 3.68 & 1.73 & 1.56 & 38.47 & 42.78 \\
\hline \multicolumn{1}{|c|}{ attenuation constant $: k N s e c / m$, spring constant $: \mathrm{kN} / \mathrm{m}$}
\end{tabular}

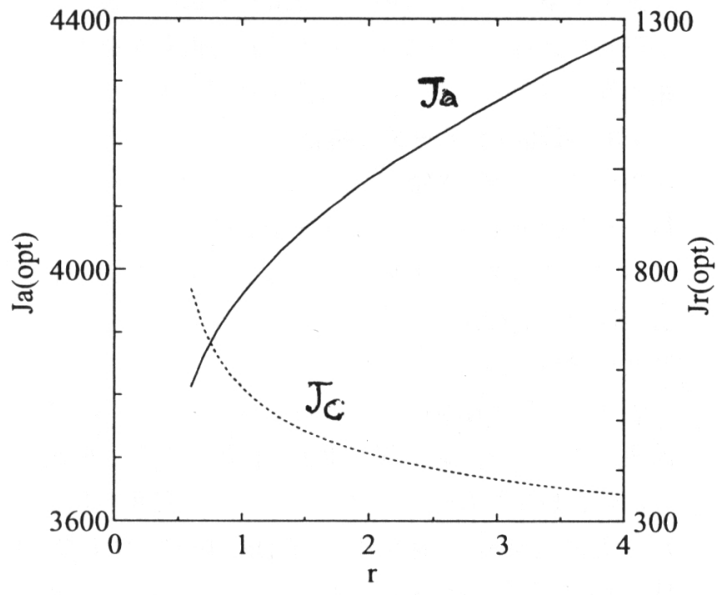

Fig. 7 Relation between $r$ and $J_{a}, J_{c}$

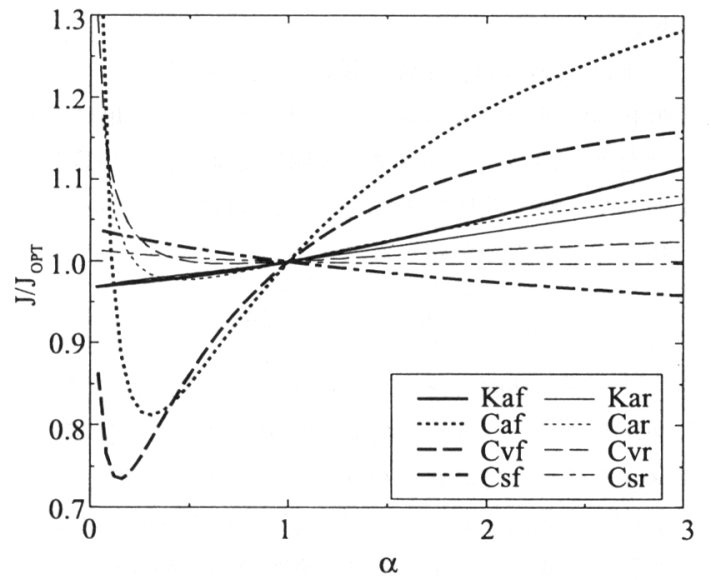

Fig. 8 Relation between $J$ and design parameters 


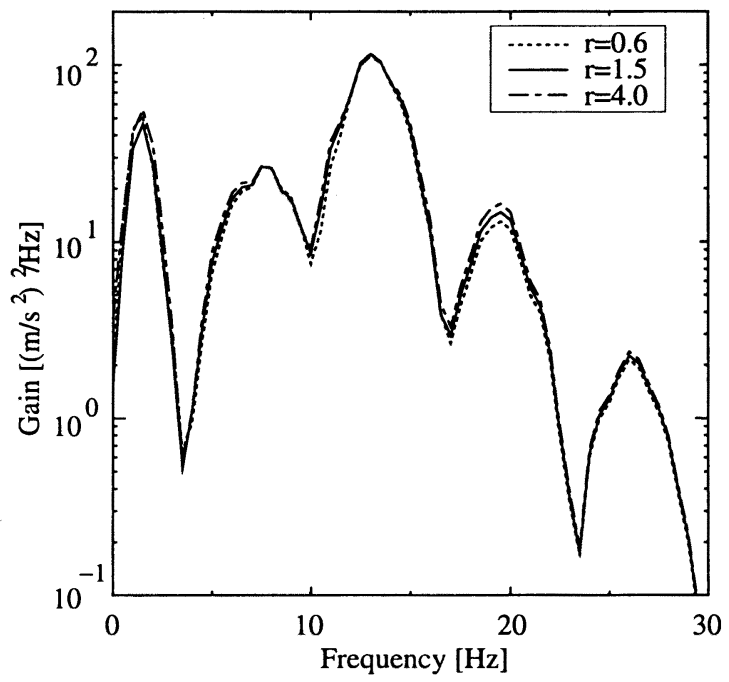

Fig. 9 Relation of $r$ and ride feeling

等式拘束条件により求められた解が最適解であること が確認できる.このことより不等式拘束条件を等式拘 束条件とみなしたことの妥当性が確認できた.

$5 \cdot 3$ 最適パラメータの特性 表 1 のパラメータ を用いてランダム路面入力シミュレーションを行い, 得られた結果をパワースペクトル解析することによっ てパワースペクトル密度を求めることができる．乗り 心地性能と消費流量性能について, パワースペクトル 密度を求める.

図 9 は, 乗り心地性能について示しており, 縦軸は 前後サスペンション上部のボディ位置での上下加速度 を足し合わせたもののパワースペクトル密度である. $r$ の変化と乗り心地性能は, $5 \mathrm{~Hz}, 10 \mathrm{~Hz}$ および 20 $\mathrm{Hz}$ 付近で関係性があるといえる. $1 \mathrm{~Hz}$ 付近の車両 のばね上共振付近では，rの変化に対して変化が小さ h.

また, 図 10 は, 性費流量性能について示しており, 縦軸は, 前後サスペンションの $\left|\dot{x}_{2}-\dot{x}_{b}\right|$ を足し合わ せたもののパワースペクトル密度である，rの変化に 対して,すべての周波数領域ではほほ同じレベルで変 化していることがわかる.

\section{6. 結 論}

ランダム路面入カシミュレーションを用いてアクテ イブサスペンションの機構パラメータおよび制御パラ メータについて最適化を行い以下の結論を得た。

(1) 8 自由度ランダム路面入力シミュレーション を利用することにより, 前後輪を同時に最適化するこ

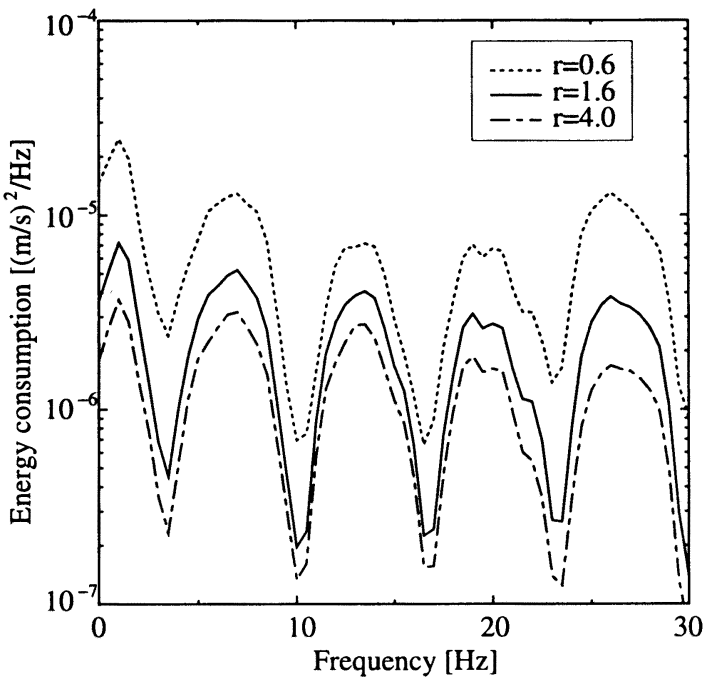

Fig. 10 Relation of $r$ and energy consumption

とができ，より実物に近い設計を行うことができた。

(2) 機構系と制御系の計 8 変数に対して, 適切な 不等式拘束条件を用いることにより, 設計変数の自由 度を下げ, 2 変数の最適化により最適設計を行うこと ができた。

（3）前後輪別々にパラメータの最適化を行うこと によって, 前輪ではパラメータの変化によって評価値 が大きく変化するが, 後輪では前輪に比べパラメータ の変化による評価值の影響が小さいことがわかった。

（4）評価関数で使用した重み変数の変化に対し て, 乗り心地性能では, 一部の周波数領域において変 化が見られ，消費流量性能では，すべての周波数領域 においてほぼ同じレベルの変化が見られることが確認 できた。

\section{文献}

（1）浜平大・花村良太・荒木嘉昭・大屋勝敬, $H \infty$ 制御を用 いた自動車のアクティブサスペンション接地荷重制御, 日本機械学会第 6 回「運動と振動の制御」シンポジウム 講演論文集, (1999-3, 18, 19, 千葉).

(2) Kim, W. and Won, S., Parameter Adaptive Gain Scheduling Control of an Active Suspension System, Proc. 4th International Symposium on Advanced Vehicle Control, (1998), 51-55.

（3）福島直人, ランダム路面入カシミュレーション手法によ る車両振動設計, 計算工学講演会論文集, 8-2 (2003), 463466.

（4）山川新二, ISO/TC 108 自動車振動規格の動向一路面山凸 表示に関する規格を中心として一, 自動車技術会学術講 演会前刷集, No. 851（1985-5)，135-138.

（5）福島直人・入江南海雄・赤津洋介・佐藤正春 - 高橋俊春, 油圧アクティブサスペンションによる車両の振動制御, 機論, 57-535, C (1991), 76-80. 